\title{
Twice Removed \\ [Transcripts]
}

\author{
Barbara McGill Balfour
}

Dans Twice Removed, sept vidéos analytiques d'une durée approximative de trois heures, je remarque que je n'ai jamais compris l'attrait de l'analyse freudienne et que je pourrais tout autant parler dans un magnétophone. Le vidéo-documentaire résultant est la manifestation de ce désir. Comme l'analyste, j'ai écouté silencieusement, attentivement pour la majeure partie, mais je peux percevoir lorsque mon esprit vagabonde, quand je ne m'écoute pas. Twice Removed révèle ma relation conflictuelle avec la thérapie. J'en suis sceptique, refusant parfois de croire en elle, puis je l'embrasse, seulement pour me demander, honteusement, si jen'y prends pas trop plaisir. Les transcriptions suivantes sont issues de Twice Removed.

In Twice Removed, seven analytical video sessions adding up to almost three hours, I remark that I never understood the attraction of Freudian analysis and that I might as well talk into a tape recorder. The resulting video documentation is the manifestation of that desire. Like the analyst, I listened silently, attentively for the most part, but I can detect when my mind is wandering, when I'm not really listening to myself. Twice Removed reveals my conflicted relationship to therapy. I am sceptical of it, refuse at times to believe in it, then embrace it only to wonder, guiltily, if I'm enjoying it too much. The following transcripts are excerpted from Twice Removed.

\section{米米米米米米}

I'm building up to something... In a way I'm trying to remember what is the root or what causes what I would call unhappiness... It's odd because at the moment when I sit down to reflect upon it I'm usually not in the midst of it... Sometimes in my jourmals I've written about it and I get pretty close to it, close to that experience and either a 
deseription or analysis of what that experience is-so it comes pretty close together at that time. And I guess I have some resistance, I think... I try to figure what is the usefulness in trying to call up this unhappiness, or even think about it or name it. Sometimes I worry that it's actually counterproductive. Especially why would I want to think about it when I feel... relatively happy?

\section{楼米米米米}

I know there are people to whom I can say I'm depressed and they'll understand or sympathize, or even if it's incomprehensible to them, they'll trust me. And then there are those who, if I say I'm depressed, think me overly dramatic or pre-menstrual or just tell me to get over it. And often, on their part. I think it shows an unwillingness even to hear about it. I'm not sure what the resistance is, but that's the way it comes out. So in the end I just don't talk to those people. And I feel I have that choice.

\section{********}

I'm aware that I'm really reluctant to engage in any kind of role-playing. Sometimes Ive been asked to try it just for fun but I really resist it, it's like I canit quite glip into it... and as a result I slip out of chavacter and I step back and analyze and comment. But I canit pretend to be in something if I'm not.

\section{*********}

Maybe it's the compression of time or maybe it's just the nature of Hollywood films... Theris also Butterfield 7 with Elizabeth Taylor and in that film there are a few glimpses of her in analysis. But then theris this amazing scene where she bursts into a room, wearing a mink coat. Shes ecstatic, and she bursts into her analysts room and announces "I'm cured!". And what has also happened is that she has fallen in love. And so being happy, being in love, is the same thing as being cured in this kind of logic. But I recognize it's a really pervasive idea that 
being in love is often like being cured. Of course it doesnit mean that just because youire in a relationship youll be happy.

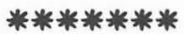

Thinking of misplacing anger also makes me think of now I intermalize it. Sometimes I donit take it out on the right person, or I take it out on the wrong person, the other altermative is taking it out on myself. As if Iim to blame, which is something I do instead of adressing the problem. I came across some advertising for a series of workshops-kind of self-help workshops, and I skimmed through them and noted that the prerequisite for a certain forgiveness workshop was the anger workshop. It struck me as quite funny but then I realized that I was torm between laughing, something about the reductive nature of labelling certain states or emotions, or even if someone has the best intentions, grouping everything under the category of anger. Somehow, well it seemed to come close to trivializing it, although Imm sure that that's not the intention. But I was really form between laughing and thinking that maybe it would be useful.

\section{米米料生米}

I remember one year when I was teaching I used a kind of fliptop type prad, which I don't think I ever used again because it wasnit practical for what I needed it for, and I was busy writing notes about students' work. One of them interrupted me and said I looked like a psychiatrist and I assured them that that was not what I was doing.

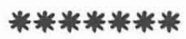

I don't know where to begin because I'm not sure of why I'm here and what I want out of this. It's not that I'm trying to figure out everything in advance; I'm just not sure what my motivation is. It's as if I need stage directions. 